remains conventional surgical reoperation. High-risk patients, however, may not tolerate reoperations. The introduction of catheter-based valve implantation has produced a new option of a valve-in-valve approach to failing bioprostheses. ${ }^{2}$ Without the anatomic difficulties associated with transcutaneous valve implantation in a native mitral annulus or a preexisting mitral annuloplasty ring, performance of the MVinV procedure is relatively straightforward because of the circular bioprosthesis sewing ring, which serves as an excellent landing zone for the transcutaneous valve stent.

Cheung and colleagues ${ }^{3}$ reported a small series of 11 patients (mean Society of Thoracic Surgeons score of 16\%) with symptomatic mitral prosthetic valve dysfunction who underwent transapical MVinV. The success rate was $100 \%$, with no 30-day mortality. Nine patients were alive and in New York Heart Association class I or II at a median follow-up of 357 days. ${ }^{3}$ Similarly, Seiffert and associates ${ }^{4}$ reported on 6 high-risk patients (EuroSCORE of 33\%) who underwent MVinV. Implantation was successful in all patients, with reduction of the transvalvular gradients and median regurgitation from grade 3 to 0 . All patients in these studies received a balloon-expandable bovine SAPIEN valve. Despite the fact that Seiffert and associates ${ }^{4}$ reported postoperative complications in 3 patients, this approach remains acceptable for high-risk patients with a failed bioprosthetic MV. As this case report demonstrates, the transapical method allows access to the AV and MV, even during the same procedure for patients at very high risk requiring reoperative double valve replacement. ${ }^{5}$ The unique aspect of this case report is that the patient had undergone a previous TA-AVI procedure. Despite the fact that the apex had previously been used for a TA-AVI operation, we did not have any difficulties with mobilization or cannulation of the apex during the MVinV procedure.

With a growing need for reoperative MV replacement for bioprosthetic structural valve deterioration, transcatheter MVinV placement has become as an alternate option. $\mathrm{Al}-$ though the evidence for this approach is limited to a few case reports and small case series, it appears to be a feasible, safe, and promising approach in a select patient population.

\section{References}

1. Holzhey DM, Schuler G, Mohr FW, Mukherjee C. Transapical double valve implantation plus percutaneous revascularization as a bailout for a high-risk patient. J Thorac Cardiovasc Surg. 2012;144:508-10.

2. Núñez-Gil IJ, Gonçalves A, Rodríguez E, Cobiella J, Marcos-Alberca P, Maroto L, et al. Transapical mitral valve-in-valve implantation: a novel approach guided by three-dimensional transoesophageal echocardiography. Eur J Echocardiogr. 2011;12:335-7.

3. Cheung AW, Gurvitch R, Ye J, Wood D, Lichtenstein SV, Thompson C, et al Transcatheter transapical mitral valve-in-valve implantations for a failed bioprosthesis: a case series. J Thorac Cardiovasc Surg. 2011;141:711-5.

4. Seiffert M, Conradi L, Baldus S, Schirmer J, Knap M, Blankenberg S, et al. Transcatheter mitral valve-in-valve implantation in patients with degenerated bioprostheses. JACC Cardiovasc Interv. 2012;5:341-9.

5. Seiffert M, Baldus S, Conradi L, Koschyk D, Schirmer J, Meinertz T, et al. Simultaneous transcatheter aortic and mitral valve-in-valve implantation in a patient with degenerated bioprostheses and high surgical risk. Thorac Cardiovasc Surg. 2011;59:490-2

\title{
Total artificial heart for patients with allograft failure
}

\author{
Mohammed A. Quader, MD, ${ }^{\mathrm{a}}$ Daniel Tang, MD, ${ }^{\mathrm{a}}$ Gundars Katlaps, MD, ${ }^{\mathrm{a}}$ Keyur B. Shah, MD, ${ }^{\mathrm{b}}$ and \\ Vigneshwar Kasirajan, MD, ${ }^{\mathrm{a}}$ Richmond, Va
}

Allograft failure may limit survival after heart transplant (HTx). For many patients with primary graft failure or chronic allograft vasculopathy retransplantation is the only treatment option. However, presensitization and limited donor heart availability may prolong wait times.

\footnotetext{
From the Division of Cardiothoracic Surgery, ${ }^{\mathrm{a}}$ and Division of Cardiology, ${ }^{\mathrm{b}}$ Virginia Commonwealth University Health System, Richmond, Va.

Disclosures: Authors have nothing to disclose with regard to commercial support.

Received for publication April 18, 2012; revisions received July 3, 2012; accepted for publication Oct 26, 2012; available ahead of print Nov 23, 2012.

Address for reprints: Mohammed A. Quader, MD, Division of Cardiothoracic Surgery, PO Box 980068, Richmond, VA 23298-0068 (E-mail: mquader@mcvh-vcu.edu). J Thorac Cardiovasc Surg 2013;145:e21-3 0022-5223/\$0.00

Published by Elsevier Inc. on behalf of The American Association for Thoracic Surgery

http://dx.doi.org/10.1016/j.jtcvs.2012.10.050
}

Because allograft failure frequently manifests as biventricular dysfunction, left ventricular assist devices (LVADs) often provide inadequate support. Biventricular assist device support has been used successfully in the past, ${ }^{1}$ but remains challenging due to anatomic constraints with small ventricles. The total artificial heart (TAH) (Syncardia, Inc, Tucson, Ariz) overcomes these limitations and can successfully support patients with allograft failure. ${ }^{2}$ We present our experience with 5 patients who presented with allograft failure and were supported with a TAH.

\section{CLINICAL SUMMARY}

Patient characteristics are described in Table 1. The patients' ages ranged from 19 to 61 years, and 3 were men. The time from transplantation to TAH placement was 
TABLE 1. Patient characteristics and outcomes after total artificial heart (TAH) placement

\begin{tabular}{|c|c|c|c|c|c|}
\hline & Patient 1 & Patient 2 & Patient 3 & Patient 4 & Patient 5 \\
\hline Age (y) & 19 & 61 & 44 & 42 & 49 \\
\hline Sex & Male & Male & Female & Female & Male \\
\hline Etiology of HF & $\begin{array}{l}\text { Muscular } \\
\text { dystrophy related }\end{array}$ & $\begin{array}{l}\text { Ischemic } \\
\text { cardiomyopathy }\end{array}$ & $\begin{array}{l}\text { Postpartum } \\
\text { cardiomyopathy }\end{array}$ & $\begin{array}{l}\text { Nonischemic } \\
\text { cardiomyopathy }\end{array}$ & $\begin{array}{l}\text { Viral } \\
\text { cardiomyopathy }\end{array}$ \\
\hline $\begin{array}{l}\text { Time since HTx } \\
\text { to TAH }\end{array}$ & $114 \mathrm{~d}$ & $1 \mathrm{~d}$ & $18 \mathrm{y}$ & $4 d$ & $7 y$ \\
\hline HTx technique & Bicaval & Bicaval & Biatrial & Bicaval & Biatrial \\
\hline $\begin{array}{l}\text { Etiology of } \\
\text { graft failure }\end{array}$ & Acute rejection & Primary graft failure & Allograft vascuopathy & Primary graft failure & Allograft vasculopathy \\
\hline Days on TAH & 32 & 79 & 225 & 425 & 346 \\
\hline Repeat HTx & No & No & Yes & No & No \\
\hline Outcome & Died of delayed bleeding & Died of sepsis & Alive & Alive & Alive \\
\hline
\end{tabular}

$H F$, Heart failure; $H T x$, heart transplant.

1 day to 18 years. Etiology of graft failure was primary graft failure ( 2 patients), acute rejection in 1 patient, and severe chronic allograft vasculopathy in 2 patients. Despite maximal medical treatment with multiple inotropes, mechanical circulatory support with intra-aortic balloon pump, and/or extracorporeal membrane oxygenation, all patients had evidence of multisystem organ failure (MSOF).

Following redo sternotomy and dissection patients were placed on cardiopulmonary support via arterial cannula in the ascending aorta and venous drainage via bicaval cannulation. Biventricular excision was performed with a small rim of ventricular tissue left on the atrial cuffs. Following TAH implantation, immunosuppression was withdrawn completely in all patients.

The duration of TAH support ranged from 32 to 425 days and end organ recovery was observed in all but 1 patient who died of sepsis after 79 days of TAH support. One patient experienced catastrophic bleeding from the aortic suture line on postoperative day 23 that led to acute deterioration and rapid MSOF leading to death. Of the 3 surviving patients, 1 received HTx after 225 days of TAH support. At the time of HTx the previous atrial tissue appeared viable without any evidence of gross necrosis or fibrosis despite the absence of immunosuppression. She is doing well 7 months after undergoing retransplantation.

The remaining 2 patients were sent home with a portable driver for the TAH for a total of 382 days. Treatments for markedly elevated panel reactive antibodies are extending the transplantation wait times.

\section{DISCUSSION}

Primary graft failure accounts for $40 \%$ of deaths in first 30 days after $\mathrm{HTx}^{3}$ and coronary vasculopathy limits long-term allograft survival. Steps designed to optimize and utilize more potential heart donors, including accepting hearts from donors aged 55 years and older, also increase risk of allograft vasculopathy. ${ }^{3}$ Mechanical circulatory support for graft failure has primarily relied on LVADs. Small ventricular chambers and associated thrombi limit the technical aspect of LVAD implantation. Because allograft failure is often a biventricular problem, outcomes with LVAD support alone have been poor. ${ }^{4}$ Most available biventricular support devices require graft ventricles to be in place, and thus patients need ongoing immunosuppression. The high doses of immunosuppressive drugs used in these very ill patients can adversely affect wound healing, susceptibility to sepsis, and increase the risk of MSOF-all leading to poor outcomes. Once a TAH is implanted we discontinue all immunosuppressants. Although donor atria from previous transplantations are left in place, it is of concern that lack of ongoing immunosuppression would lead to atrial wall necrosis, predisposing to atrial suture line dehiscence from potential tissue necrosis. We did not find this to be a problem in any of our patients. At the time of repeat transplantation, we followed bicaval heart implantation technique. Atria from the previous transplantation appeared viable with no evidence of necrosis.

The TAH is a biventricular support system and can restore a cardiac output of up to $10 \mathrm{~L} /$ minute. This helps reverse the MSOF often encountered in patients with advanced graft failure. ${ }^{5}$ We observed this in all but 1 patient. Bleeding, sepsis, and sensitization present challenges in the postoperative care of these patients. The latter 3 of our patients survived the initial biventricular failure with a more expedient TAH implant. After successful recovery we were able to discharge them to home with a portable driver.

For failing cardiac allografts without potential for recovery, we find the TAH to be an effective bridge for patients eligible for retransplantation. However, overcoming issues related to bleeding, infections, and sensitization continue to be challenges after TAH implantation.

\section{References}

1. Tenderich G, Koerner MM, Stuettgen B, Minami K, El-Banayosy A, Arusoglu L, et al. Mechanical circulatory support after orthotopic heart transplantation. Int J Artif Organs. 1998;21:414-6. 
2. Yoda M, El-Banayosy A, Tenderich G, Koerfer R, Minami K. The CardioWest total artificial heart for chronic heart transplant rejection. Circ J. 2009;73:1167-8.

3. Stehlik J, Edwards LB, Kucheryavaya AY, Benden C, Christie JD, Dobbels F, et al. The Registry of the International Society for Heart and Lung Transplantation: twenty-eighth adult heart transplant report-2011. J Heart Lung Transplant. 2011;30:1078-94.
4. Minev PA, El-Banayosy A, Minami K, Kortke H, Kizner L, Korfer R. Differentia indication for mechanical circulatory support following heart transplantation. Intensive Care Med. 2001;27:1321-7.

5. Copeland JG, Copeland H, Gustafson M, Mineburg N, Covington D, Smith RG, et al. Experience with more than 100 total artificial heart implants. Journal Cardiovasc Surg. 2012;143:727-34.

\title{
HeartWare ventricular assist device placement in a patient with congenitally corrected transposition of the great arteries
}

\author{
Jiapeng Huang, MD, PhD, ${ }^{\mathrm{a}, \mathrm{b}}$ and Mark S. Slaughter, MD,${ }^{\mathrm{c}}$ Louisville, Ky
}

Congenitally corrected transposition of the great arteries (CC-TGA) is a rare anomaly that is seen in fewer than $0.5 \%$ of patients with clinically evident congenital heart disease. Failure of the systemic ventricle (morphologically right ventricle $[\mathrm{RV}]$ ) is the main cause of heart failure. ${ }^{1}$ Heart transplant is the treatment of choice for most patients with CC-TGA who are in end-stage heart failure. Ventricular assist devices (VADs) may become necessary to deal with progressive decline of end-organ function during the wait for an appropriate donor. Patients with CC-TGA present unique challenges for VAD implantation and management.

\section{CLINICAL SUMMARY}

A 66-year-old man with a diagnosis of CC-TGA was seen at an outside hospital for worsening shortness of breath. He had shown slow progression to New York Heart Association functional class IV symptoms during the previous 8 years. His medical history was also significant for chronic atrial fibrillation and dyslipidemia. He was started on a continuous milrinone infusion of $0.3 \mu \mathrm{g} /(\mathrm{kg} \cdot \mathrm{min})$ and transferred to our hospital for possible VAD placement.

The patient's preoperative hemodynamic values with milrinone infusion were as follows: blood pressure, 110/65 mm Hg; heart rate, 90 beats/min; cardiac index,

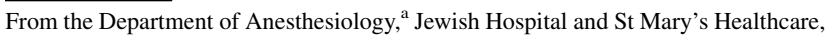
Louisville, Ky; and the Department of Anesthesiology and Perioperative Medici$\mathrm{ne}^{\mathrm{b}}$ and the Division of Thoracic and Cardiovascular Surgery, ${ }^{\mathrm{c}}$ Department of Surgery, University of Louisville, Louisville, Ky.

Disclosures: Dr Slaughter received education/training grant support from HeartWare, Inc. The other author has nothing to disclose with regard to commercial support.

HeartWare ventricular assist device is manufactured by HeartWare, Inc, Miramar, Fla. Received for publication June 21, 2012; revisions received Oct 10, 2012; accepted for publication Nov 6, 2012; available ahead of print Dec 10, 2012.

Address for reprints: Jiapeng Huang, MD, PhD, 200 Abraham Flexner Way,

Louisville, KY 40202 (E-mail: jiapenghuang@yahoo.com).

J Thorac Cardiovasc Surg 2013;145:e23-5

$0022-5223 / \$ 36.00$

Copyright (c) 2013 by The American Association for Thoracic Surgery

http://dx.doi.org/10.1016/j.jtcvs.2012.11.008
}

$1.65 \mathrm{~L} /\left(\min \cdot \mathrm{m}^{2}\right)$, and pulmonary vascular resistance, 129 dynes $/\left(\mathrm{s} \cdot \mathrm{cm}^{-5}\right)$. After induction of general anesthesia, transesophageal echocardiography (TEE) was performed. The moderator band and the inferior insertion of the atrioventricular valve leaflets helped to identify the leftpositioned ventricle as the morphologically $\mathrm{RV}$ and the associated valve as the tricuspid valve. The tricuspid valve was trileaflet, with a large prolapsed septal leaflet, a small anterior leaflet, and a cleft posterior leaflet. The tricuspid annulus was dilated to $49 \mathrm{~mm}$, and color flow Doppler ultrasonography demonstrated severe tricuspid regurgitation. The ejection fraction of the morphologically RV was only $20 \%$, with RV end-diastolic diameter of $8.7 \mathrm{~cm}$. The pulmonary ventricle (morphologically left ventricle) function was nearly normal, with an ejection fraction of $50 \%$.

A standard sternotomy was performed. The systemic aorta and right atrium were cannulated, and cardiopulmonary bypass was established. Because of concerns that the moderator band and multiple papillary muscles in the RV might obstruct the VAD inflow cannula, an 18-gauge angiocatheter was inserted into the RV, and agitated saline solution was injected to determine the optimal angle for the VAD inflow cannula. When the tip of the angiocatheter was found to be in the mid RV cavity without obvious obstruction, the sewing ring was sutured and ventriculotomy was then performed with the punch. On visual inspection, there were no significant crossing fibers. A HeartWare HVAD (HeartWare, Inc, Miramar, Fla) was then inserted with its center in the predetermined site. The outflow cannula was then anastomosed to the systemic aorta with a partially occluding aortic clamp. TEE verified that the VAD inflow cannula was positioned parallel to the interventricular septum without significant obstruction. Initially, a pump flow of $3.5 \mathrm{~L} / \mathrm{min}$ was achieved after weaning off cardiopulmonary bypass. The device was positioned in the mediastinum, and the outflow graft was placed in the pericardial well (Figures 1 and 2).

Postoperatively, the patient did well hemodynamically and had good pump performance. On postoperative day 